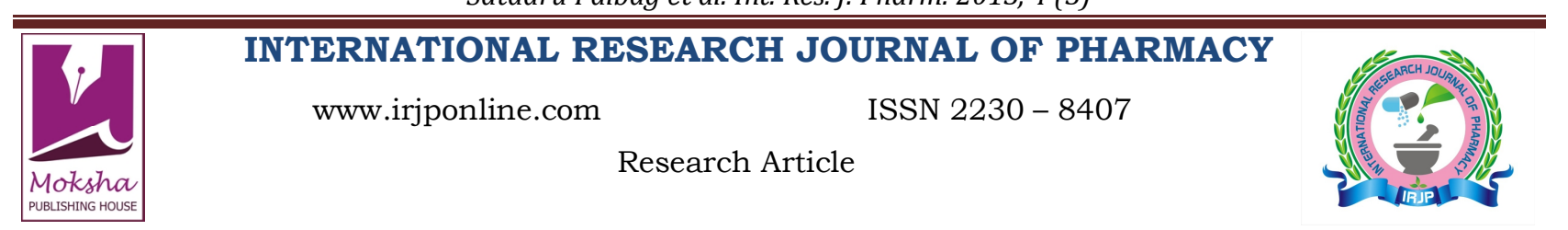

\title{
QUALITATIVE EVALUATION OF MARKETED AYURVEDIC RED TOOTH POWDER BY NAMBURI PHASED SPOT TEST
}

Satadru Palbag, Varun Kumar Singh, Narendra Kumar Singh, D.N.S. Gautam*

Faculty of Ayurveda, Institute of Medical Sciences, Banaras Hindu University, Varanasi-221005 India

Email: drdnsgautam@gmail.com

Article Received on: 12/01/13 Revised on: 01/02/13 Approved for publication: 13/03/13

DOI: $10.7897 / 2230-8407.04324$

IRJP is an official publication of Moksha Publishing House. Website: www.mokshaph.com

(C) All rights reserved.

\section{ABSTRACT}

Simple and precise quality control analysis of consumer goods is the goal of rising FMCG sector. Ayurvedic red tooth powders are one of the most popular FMCG products in today's market. The main ingredient $(\geq 80 \%)$ of these red tooth powders is Swarna gairik (Red Hematite), thus the qualitative evaluation of red tooth powder can be performed by analysis of Swarna gairik. Objective of present study is to develop a simple yet precise method for the quality evaluation of Ayurvedic red tooth powders. Three marketed samples of red tooth powders S-1, S-2 and S-3 were evaluated by Namburi phased spot test against a control sample C. The variation of color and pattern of the spots were carefully evaluated at three distinct time phases. There were marked differences among the color and pattern of the spots for all the three samples when compared with the control, C. Study revealed that S-1 contains standard Swarna gairik whereas S-2 and S-3 contains spurious Swarna gairik. We concluded that the NST is a simple and dependable technique for the evaluation of Ayurvedic red tooth powder.

Keywords: Namburi phased spot test, Swarna gairik, FMCG.

\section{INTRODUCTION}

In Ayurvedic iatrochemistry Gairik comes under Uparasa group ${ }^{1}$. It is a red colored mineral containing iron and oxygen with a chemical formula of $\mathrm{Fe}_{2} \mathrm{O}_{3}{ }^{2}$. According to the Ayurvedic classic 'Rasendra Churamani', Gairik is of two varieties, Swarna gairik and Pasan gairik. Pasan gairik is more compact with copperish tint whereas Swarna gairik is red colored in color having haemostatic property ${ }^{3}$ and gritty in texture, hence it is very effective in bleeding gums and act as natural scrubber and abrasive. This is the very reason why it is the drug of choice for preparing red tooth powder by Ayurvedic companies in first moving consumer goods (FMCG) sector. Besides Swarna gairik, other important ingredients of an Ayurvedic red tooth powder are dried herbs of Zinziber officinale, Piper longum, Piper nigram, Cinnamomum camphora, Xanthoxylum alatum, Syzygium aromaticum oil, etc. All these herbs collectively fight against several dental problems. Namburi phased spot test (NST) is comparatively an easy test for determining the quality of a given Ayurvedic minerals and bhasma. NST was developed by Dr. Namburi Hanumantha Rao, in 1970 and has been accepted by CCRAS, New Delhi. In this test a drop of clear solution of bhasma or minerals previously treated with aquaregia, is impinged on the chemically treated filter paper, formation of colored spot takes place. NST study involves the careful observation of the spots with its color at three successive stages of time ( $1^{\text {st }}$ phase: 0 to $5 \mathrm{~min}, 2^{\text {nd }}$ phase: 5 min to $20 \mathrm{~min}, 3^{\text {rd }}$ phase: $20 \mathrm{~min}$ to one day) $)^{4}$. Thus NST study measures the chemical reactions at every interval of time. The identification of elements and assessment of its percentage composition in a given bhasma or mineral is not sufficient to assess its quality. Quality differences, stability and density (migration rate) of the bhasma are also considered necessary for which the NST is very optimum and satisfactory. Though during administration Swarna gairik is not used in its bhasma form, but still there are standard protocols developed by Dr. N. H. Rao, for the comparison of standard Gairik from its spurious form by NST. In the present study we developed a simple yet accurate analytical method for the qualitative evaluation of marketed Ayurvedic red tooth powder by NST method.

\section{MATERIALS AND METHODS \\ Preparation of the samples}

Three marketed Ayurvedic tooth powders of 100 gm each were taken from the local market randomly and coded as S-1, S-2 and S-3. For the control (C), 100 gm of Swarna gairik and other dry herbs were procured from Ayurvedic pharmacy of Faculty of Ayurveda, Banaras Hindu University, Varanasi. It was then purified by frying in ghee, at low flame ${ }^{5}$. For the simulation of control $\mathrm{C}$ with the marketed Ayurvedic red tooth powders, Swarna gairik was mixed with powder of Acacia arabica bark, Zinziber officinale, Piper longum, Piper nigram, Cinnamomum camphora, Syzygium aromaticum oil, Terminalia chebula and Xanthoxylum alatum seed. All the dry herbs were previously grinded to form coarse powder. Among the marketed samples, S-1 contained all the above herbs, S-2 was devoid of bark powder of Acacia arabica and S-3 was devoid of Terminalia chebula powder. The quantity of these ingredients added with the control $\mathrm{C}$ was determined by the mean quantity of every single ingredient in the marketed samples of S-1, S-2 and S-3. Additional Acacia arabica bark powder and Terminalia chebula powder was mixed with S-2 and S-3 respectively to maintain the uniformity of the samples (Table I).

\section{Namburi phased spot test ${ }^{4}$}

Four Whatman's filter paper no-1 were taken and impinged with $2.5 \%$ potassium ferrocyanide solution and dried. 0.25 gm of C, S-1, S-2 and S-3 were heated for one minute on water bath and taken in a centrifuge tube. All the samples were treated with $0.5 \mathrm{ml}$ aquaregia in the centrifuge tube and after 30 minutes heated for one minute on the water bath. Samples were shaken for every now and then for 18 hours. It was then allowed to settle to form a clear supernatant liquid (Figure 1), in the centrifuge tube. Two drop of supernatant liquid was placed on the previously prepared potassium 
ferrocyanide paper. Color variations were carefully observed after three time phases (Figure 2).

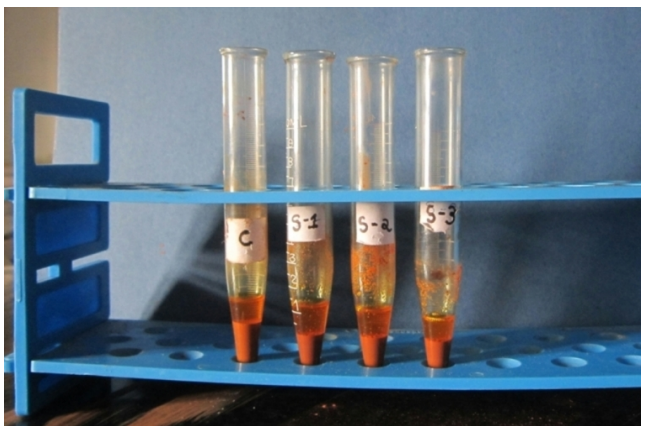

Figure 1: Samples of red tooth powders in their respective centrifuge tubes, after 18 hours

Phase 1

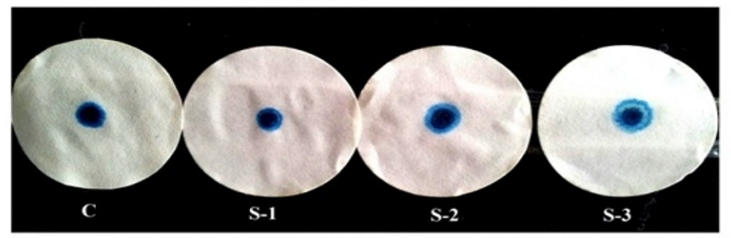

Phase2

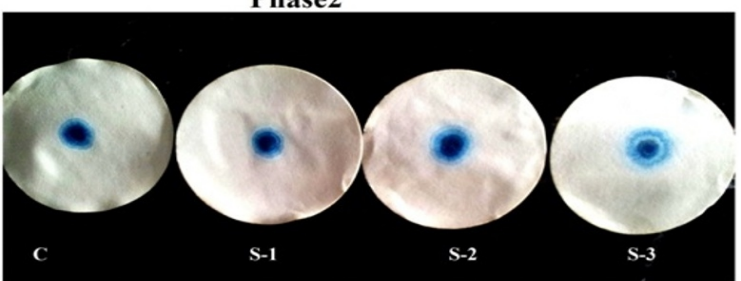

Phase 3

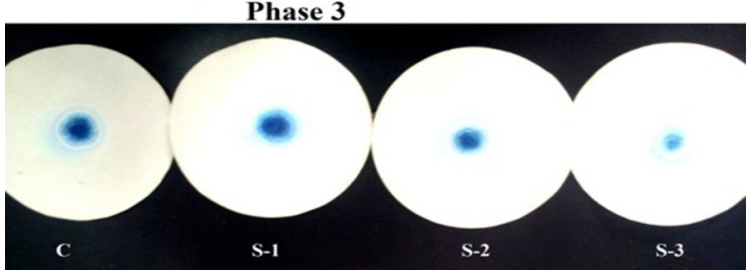

Figure 2: NST test of the samples, at three successive time phases

Table I: Ingredients along with Gairik in all the four samples of tooth powder

\begin{tabular}{|c|c|c|c|c|c|}
\hline Ingredients & Quantity & C & S-1 & S-2 & S-3 \\
\hline Acacia arabica & $2 \mathrm{gm}$ & Added separately & Present in the sample. & Added separately & Present in the sample. \\
\hline Zinziber officinale & $3 \mathrm{gm}$ & Added separately & Present in the sample. & Present in the sample. & Present in the sample. \\
\hline Piper longum & $3 \mathrm{gm}$ & Added separately & Present in the sample. & Present in the sample. & Present in the sample. \\
\hline Piper nigram & $3 \mathrm{gm}$ & Added separately & Present in the sample. & Present in the sample. & Present in the sample. \\
\hline Cinnamomum camphora & $3 \mathrm{gm}$ & Added separately & Present in the sample. & Present in the sample. & Present in the sample. \\
\hline Syzygium aromaticum & $1 \mathrm{gm}$ & Added separately & Present in the sample. & Present in the sample. & Present in the sample. \\
\hline Terminalia chebula & $2 \mathrm{gm}$ & Added separately & Present in the sample. & Present in the sample. & Added separately \\
\hline Xanthoxylum alatum & $2 \mathrm{gm}$ & Added separately & Present in the sample. & Present in the sample. & Present in the sample. \\
\hline
\end{tabular}

Table II: NST of all the four samples of tooth powder

\begin{tabular}{|c|c|c|c|c|}
\hline Phase & C & S-1 & S-2 & S-3 \\
\hline $1^{\text {st }}$ phase & $\begin{array}{l}\text { A wide deep green solid spot } \\
\text { formed, along with a very thin } \\
\text { light green periphery. }\end{array}$ & $\begin{array}{l}\text { A wide deep green solid spot } \\
\text { formed, along with a very } \\
\text { thin light green periphery }\end{array}$ & $\begin{array}{l}\text { A wide deep green solid spot } \\
\text { formed, along with a narrow } \\
\text { deep blue periphery. }\end{array}$ & $\begin{array}{l}\text { A wide deep blue solid spot } \\
\text { formed, along with a wide } \\
\text { deep blue smudged periphery. }\end{array}$ \\
\hline $2^{\text {nd }}$ phase & $\begin{array}{l}\text { Same as } 1^{\text {st }} \text { phase with deep } \\
\text { green color changed to bluish } \\
\text { green, and the periphery got } \\
\text { thickened. }\end{array}$ & $\begin{array}{l}\text { Same as } 1^{\text {st }} \text { phase with deep } \\
\text { green color changed to bluish } \\
\text { green, and the periphery got } \\
\text { thickened }\end{array}$ & $\begin{array}{l}\text { Same as } 1^{\text {st }} \text { phase, but the deep } \\
\text { blue periphery got widened and } \\
\text { thickened. }\end{array}$ & $\begin{array}{l}\text { Same as } 1^{\text {st }} \text { phase, but the } \\
\text { deep blue periphery got more } \\
\text { smudged and widened. }\end{array}$ \\
\hline $3^{\text {rd }}$ phase & $\begin{array}{l}\text { Bluish green central solid spot } \\
\text { formed deep blue solid spot, } \\
\text { whereas the periphery got } \\
\text { widened and changed to blue } \\
\text { color. }\end{array}$ & $\begin{array}{l}\text { Bluish green central solid } \\
\text { spot formed deep blue solid } \\
\text { spot, whereas the periphery } \\
\text { got widened and changes to } \\
\text { blue color. }\end{array}$ & $\begin{array}{c}\text { Bluish green central solid spot } \\
\text { changed to deep blue solid spot, } \\
\text { whereas the periphery got more } \\
\text { widened. }\end{array}$ & $\begin{array}{l}\text { Bluish green central solid spot } \\
\text { get smudged and condensed, } \\
\text { whereas the periphery got } \\
\text { almost disappeared. }\end{array}$ \\
\hline
\end{tabular}


OBSERVATION AND RESULTS

After testing all the samples for NST, marked differences in the color and pattern of the spots were found. No deviation was found for the sample $\mathrm{S}-1$ in respect to $\mathrm{C}$, but there were marked deviation in the pattern for sample S-2 and S-3 with S-3 showing a maximum deviation (Table II).

\section{DISCUSSION AND CONCLUSION}

NST is a simple and precise test, with minimum technical requirements. Differences among apparently similar minerals or bhasmas could be easily evaluated by NST as it has the capability to chemically differentiate the samples. According to the observation, the color of all the four samples C, S-1, S2 and S-3 varied to a considerable degree. C and S-1 complied with the standard protocol according to the color and shape of the spot, but S-2 and S-3 varied to a greater extent in respect to $\mathrm{C}$, hence we can conclude that sample $\mathrm{S}-2$ and S-3 contain spurious or adulterated Swarna gairik, whereas S-1 contains standard Swarna gairik. Thus by Namburi phased spot test we can easily qualitatively evaluate marketed Ayurvedic red tooth powder in FMCG sector.

\section{REFERENCES}

1. Joshi D. Rasashastra. English ed. Varanasi: Choukhamba Orientalia; 2010.p. 220

2. Joshi D, editor. Rasamritam of Yadavji Trikamji. 2nd ed. Varanasi: Choukhamba Sanskrit Bhavan; 2003.p. 102.

3. Mishra S, editor. Raendrachuramani of Somdeva. Varanasi: Choukhamba Orientalia; 2009.p. 189.

4. Rao N.H. Application of standardized Namburi phased spot test in identification of bhasma and sindura preparations of Ayurveda. New Delhi: CCRAS publication; 2010. p.73.

5. Mishra G.S, editor. Ayurved Prakash of Madhava Upadhyaya. Varanasi: Chowkhamba bharati Acadamy; 2007.p. 324.

Cite this article as:

Satadru Palbag, Varun Kumar Singh, Narendra Kumar Singh, D.N.S. Gautam. Qualitative evaluation of marketed Ayurvedic red tooth powder by Namburi phased spot test. Int. Res. J. Pharm. 2013; 4(3):128-130 